\title{
EXPERIMENTAL STUDY ON PERFORMANCE OF DIESEL ENGINE USING BIO-DIESEL
}

\author{
Vishwanath V K ${ }^{\mathbf{1}}$, Pradhan Aiyappa M R $\mathbf{R}^{\mathbf{2}}$, Aravind S Desai ${ }^{3}$ \\ ${ }^{I}$ Graduate student, Dept. of Mechanical Engineering, Nitte Meenakshi Institute of Technology, Karnataka, India \\ ${ }^{2}$ Graduate student, Dept. of Mechanical Engineering, Nitte Meenakshi Institute of Technology, Karnataka, India \\ ${ }^{3}$ Graduate student, Dept. of Mechanical Engineering, Nitte Meenakshi Institute of Technology, Karnataka, India
}

\begin{abstract}
This paper deals with the experimental investigations carried out in studying the performance analysis of 4-stroke diesel using Methyl Ester of Cotton Seed Oil (MECSO) and its blends with diesel. Bio-diesel (MECSO) has been prepared by transesterification process. Performance tests on single cylinder 4-stroke compression ignition engine have been conducted using pure bio-diesel and its blends as fuel and performance parameters are compared by diesel as fuels. Various graphs like Brake thermal efficiency, BSFC, total fuel consumption rate; speed v/s loads ranging from 0 to $16 \mathrm{Kg}$ have been plotted. The study shows that there will be a slight improvement in Brake thermal efficiency, So Methyl Ester of Cotton Seed Oil can be an alternative fuel.
\end{abstract}

Keywords-Bio-diesel, Cotton seed oil, Trans-esterification, compression ignition engine

\section{INTRODUCTION}

Traditional Diesel engine power plants are preferred where power has to be generated in small quantity or used as standby sets which are required for commercial use. In many countries the demand of fuel for diesel engines increases for much use in agriculture, transportation and power generation. But, on account of high fuel consumption of diesel fuel the need for replacement of diesel fuel became essential. Many alternative fuels for diesel engines such as vegetable oil esters, tyre pyrolysis oil, orange oil etc. were introduced in the last two decades. Utilization of biomass as alternative fuel for compression ignition engine has a great scope especially in developing and undeveloped countries. The bio mass can be converted into useful energy by adopting different techniques such as dry combustion, anaerobic digestion, bio photolysis, pyrolysis, liquefaction, gasification, hydrolysis and solvent extraction [1]. Environmental concerns and limited amount of petroleum resources have caused interests in the development of alternative fuels for I.C. Engines. Petroleum resources are finite and therefore search for their alternative is continuing all over the world. The major energy demand is fulfilled by the use of conventional energy resources like coal, petroleum and natural gas. These sources are in the verge of getting extinct. The scarcity of conventional fossil fuels, growing emissions of combustion generated pollutants and their increasing costs will make biomass sources more attractive. The use of biodiesel is rapidly expanding around the world, making it imperative to fully understand the impacts of biodiesel on the diesel engine combustion process and pollutant formation. Bio fuels like ethanol and bio-diesel being environment friendly, will help us to conform to the stricter emission norms. Bio fuels are generally considered as offering many priorities, including sustainability, reduction of greenhouse gas emissions, regional development, social structure and agriculture and security of supply. In the developed countries, there is a growing trend towards employing modern technologies and efficient bio energy conversion using a range of bio fuels, which are becoming cost-wise competitive with fossil fuels [2]. Research on vegetable oil use in diesel engine is still progressing today. The results of exhaust emissions characteristics of ordinary Malaysian coconut oil blended with conventional diesel oil in a diesel engine. The results showed that the addition of $30 \%$ coconut oil with diesel oil produced higher brake power with a net reduction in exhaust emissions. The experiments were undertaken to test a diesel engine using oil composed of cottonseed oil and conventional diesel fuel [3]. The experimental results showed that a mixing ratio of $30 \%$ cottonseed oil and $70 \%$ diesel was optimal in ensuring relatively high thermal efficiency of the engine. The use of hazelnut oil as an alternative fuel in pre-chamber diesel engines, and compared it with diesel [4]. A heat exchanger, preheated Jatropha oil has the potential to be a substitute fuel for diesel engines. Optimal fuel inlet temperature was found to be $80^{\circ} \mathrm{C}$ considering the brake thermal efficiency, brake specific energy consumption and gaseous emissions. A comparable engine performance and emissions are reported by using preheated peanut, sunflower and canola oils in two DI diesel engines. Seven non-edible vegetable oils including Jatropha oil as an alternative fuel for diesel engine [5]. The alternative diesel fuels must be technically and environmentally acceptable and economically competitive. From the view point $\mathrm{s}$ of requirements, triglycerides (vegetable oils or animal fats) and their derivatives may be considered as viable alternative for diesel fuels [6]. The vegetable oils can be used in Diesel engines by various techniques such as fuel modifications by Trans-esterification, Diesel Vegetable blends and Vegetable oil heating etc.[7]. 


\section{METHODOLOGY ADOPTED}

1. Filtering the used cotton seed oil, for a successful reaction the oil must be free of water.

2. Measuring the volume of oil to be processed.

3. Heating the oil to $35^{\circ} \mathrm{C}$.

4. Adding $300 \mathrm{ml}$ of methanol for each liter of heated oil and mixing it for 5 minutes.

5. For each liter of oil $1 \mathrm{ml}$ of $95 \%$ sulphuric acid was added.

6. The mixing was gently done at low rpm maintaining the temperature at $35{ }^{\circ} \mathrm{C}$ for one hour then heating was stopped. The stirring was continued for another hour.

7. In the meantime the sodium methoxide was prepared: $120 \mathrm{ml}$ of methanol for each liter of oil and $3 \mathrm{gms}$ of sodium hydroxide $(\mathrm{NaOH})$ per liter of oil. $\mathrm{NaOH}$ is completely dissolved.

8. After settling for 8 hours, the half of the prepared methoxide was poured into the unheated mixture and it was mixed for 5 minutes.

9. The mixture was heated to $55^{\circ} \mathrm{C}$ and the second half of the prepared methoxide was mixed to the heated mixture.

10. It was allowed to settle for 8 hours.

11. After settling for 8 hours 2 phases were obtained one was biodiesel and the other glycerin.

\section{EXPERIMENTAL SETUP}

The experimental set up includes the Redwood Viscometer, Pensky Martins Apparatus, and Kirloskar Water Cooled Diesel Engine etc.

1. Redwood Viscometer: It is used to find the viscosity of the bio-diesel. Viscosity of a fuel is defined as "the resistance offered to the movement of one layer of fuel over the adjacent layer". Kinematic Viscosity is defined as the ratio between dynamic viscosity and density of fluid.

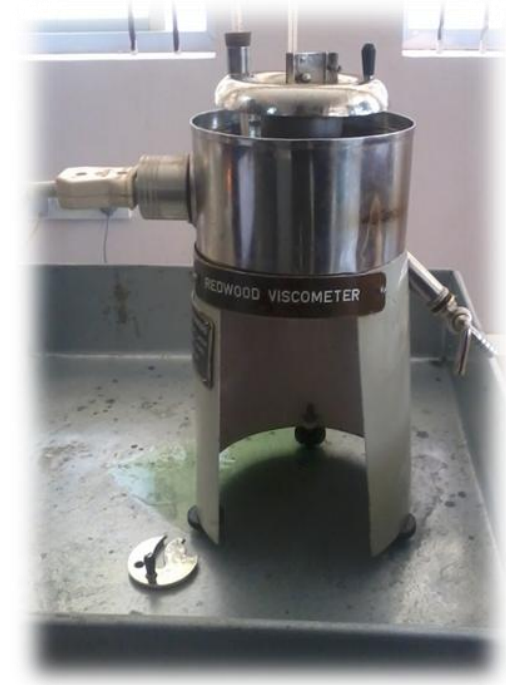

Fig 1: Redwood Viscometer
2. Pensky Martins Apparatus: It was used to find the Flash and Fire point of the bio-diesel.

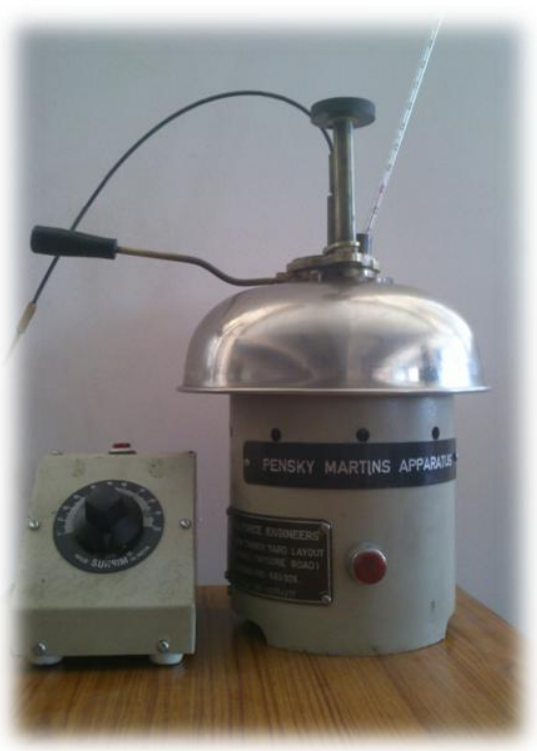

Fig 2: Pensky Martins Apparatus

3. Kirloskar Water Cooled Diesel Engine: We used single cylinder Kirloskar water cooled diesel engine for our work. The specifications of the engine is shown in the table,

Table 1: Specifications of Diesel Engine

\begin{tabular}{|l|l|}
\hline $\begin{array}{c}\text { NUMBER } \\
\text { STROKES }\end{array}$ & 4 \\
\hline $\begin{array}{c}\text { COMPRESSION } \\
\text { RATIO }\end{array}$ & $16.5: 1$ \\
\hline BORE * STROKE & $85 * 110$ \\
\hline RATED POWER & 5 HP @ 1500 RPM \\
\hline TYPE OF COOLING & WATER-COOLED \\
\hline
\end{tabular}

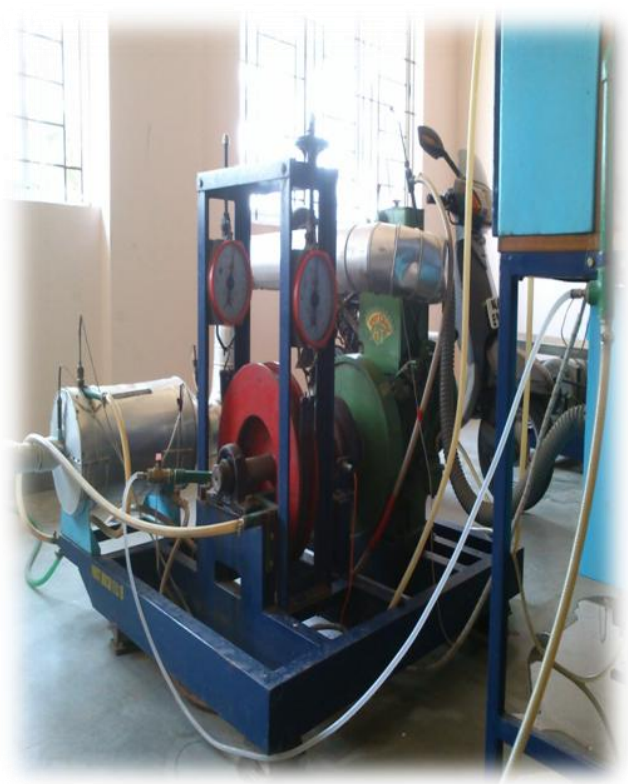

Fig 3: Kirloskar Water Cooled Diesel Engine 


\section{DATA COLLECTION AND ANALYSIS}

The table gives the various properties obtained after experimentation for Diesel and Blends of 10, 20, 40, 60, and 100.

Table 2: Properties of Bio-diesel

\begin{tabular}{|l|l|l|l|l|l|l|}
\hline \multirow{3}{*}{ Fuel } & \multicolumn{2}{|l|}{$\begin{array}{l}\text { Dynamic Viscosity } \\
* \mathbf{1 0}^{-3} \\
\left(\mathbf{N}-\mathbf{s} / \mathbf{m}^{\mathbf{2}}\right)\end{array}$} & $\begin{array}{l}\text { Calorific value } \\
(\mathbf{k J} / \mathbf{k g ~ K})\end{array}$ & $\begin{array}{l}\text { Specific } \\
\text { Gravity }\end{array}$ & $\begin{array}{l}\text { Flash Point } \\
\left({ }^{\circ} \mathbf{C}\right)\end{array}$ & $\begin{array}{l}\text { Fire point } \\
\left(\mathbf{6 0}^{\circ} \mathbf{C}\right)\end{array}$ \\
\hline Diesel & 0.855 & $\mathbf{4 0}^{\circ} \mathbf{C}$ & & & & \\
\hline B10 & 1.003 & 44172.85 & 0.832 & 55 & 65 \\
\hline B20 & 1.386 & 2.902 & 43112.92 & 0.816 & 44 & 53 \\
\hline B40 & 1.583 & 2.968 & 42543.66 & 0.826 & 49 & 61 \\
\hline B60 & 1.745 & 3.112 & 41998.91 & 0.833 & 58 & 73 \\
\hline B100 & 1.851 & 4.412 & 43389.12 & 0.846 & 78 & 93 \\
\hline
\end{tabular}

The following shows the performance of the Bio-diesel and its blends.

Table 3: Performance of B10 Blend as fuel

\begin{tabular}{|l|l|l|l|l|l|l|l|}
\hline $\begin{array}{l}\text { Load } \\
(\mathbf{k g})\end{array}$ & $\begin{array}{l}\text { Speed } \\
(\mathbf{r p m})\end{array}$ & $\begin{array}{l}\mathbf{B P} \\
(\mathbf{k W})\end{array}$ & $\begin{array}{l}\mathbf{M}_{\mathbf{f}} \\
(\mathbf{k g} / \mathbf{m i n})\end{array}$ & $\begin{array}{l}\mathbf{T F C} \\
(\mathbf{k g} / \mathbf{h r})\end{array}$ & $\begin{array}{l}\text { BSFC } \\
(\mathbf{k g} / \mathbf{K W}-\mathbf{h r})\end{array}$ & $\begin{array}{l}\text { H.I } \\
(\mathbf{k W})\end{array}$ & $\mathbf{y}_{\mathrm{b} \text { th }}(\boldsymbol{\%})$ \\
\hline 0 & 1649 & 0 & 0.008526 & 0.51156 & 1 & 5.667 & 0 \\
\hline 4 & 1568 & 1.127 & 0.0102 & 0.612 & 0.5518 & 6.78 & 11.591 \\
\hline 8 & 1554 & 2.365 & 0.0134 & 0.804 & 0.3623 & 8.909 & 25.681 \\
\hline 12 & 1538 & 3.358 & 0.01827 & 1.0962 & 0.3293 & 12.143 & 29.892 \\
\hline 16 & 1526 & 4.421 & 0.0222 & 1.332 & 0.3 & 14.756 & 33.46 \\
\hline
\end{tabular}

Table 4: Performance of B20 Blend as fuel

\begin{tabular}{|l|l|l|l|l|l|l|l|}
\hline $\begin{array}{l}\text { Load } \\
(\mathbf{k g})\end{array}$ & $\begin{array}{l}\text { Speed } \\
(\mathbf{r p m})\end{array}$ & $\begin{array}{l}\text { BP } \\
(\mathbf{k W})\end{array}$ & $\begin{array}{l}\mathbf{M}_{\mathbf{f}} \\
(\mathbf{k g} / \mathbf{m i n})\end{array}$ & $\begin{array}{l}\text { TFC } \\
(\mathbf{k g} / \mathbf{h r})\end{array}$ & $\begin{array}{l}\text { BSFC } \\
(\mathbf{k g} / \mathbf{k W}-\mathbf{h r})\end{array}$ & $\begin{array}{l}\text { H.I } \\
(\mathbf{k W})\end{array}$ & $\begin{array}{l}\mathbf{\eta}_{\mathbf{b} \text { th }} \\
(\%)\end{array}$ \\
\hline 0 & 1649 & 0 & 0.008552 & 0.51312 & 1 & 5.666 & 0 \\
\hline 4 & 1568 & 1.224 & 0.009681 & 0.58086 & 0.523 & 6.4156 & 12.57 \\
\hline 8 & 1554 & 2.485 & 0.0114 & 0.684 & 0.3082 & 7.554 & 26.82 \\
\hline 12 & 1538 & 3.387 & 0.0165 & 0.99 & 0.2974 & 10.934 & 31.79 \\
\hline 16 & 1526 & 4.518 & 0.0205 & 1.23 & 0.2771 & 13.582 & 37.42 \\
\hline
\end{tabular}

Table 5: Performance of B40 Blend as fuel

\begin{tabular}{|l|l|l|l|l|l|l|l|}
\hline $\begin{array}{l}\text { Load } \\
(\mathbf{k g})\end{array}$ & $\begin{array}{l}\text { Speed } \\
(\mathbf{r p m})\end{array}$ & $\begin{array}{l}\mathbf{B P} \\
(\mathbf{k W})\end{array}$ & $\begin{array}{l}\mathbf{M}_{\mathbf{f}} \\
(\mathbf{k g} / \mathbf{m i n})\end{array}$ & $\begin{array}{l}\text { TFC } \\
(\mathbf{k g} / \mathbf{h r})\end{array}$ & $\begin{array}{l}\text { BSFC } \\
(\mathbf{k g} / \mathbf{k W}-\mathbf{h r})\end{array}$ & $\begin{array}{l}\text { H.I } \\
(\mathbf{k W})\end{array}$ & $\begin{array}{l}\mathbf{D}_{\mathbf{b} \text { th }} \\
(\mathbf{\%})\end{array}$ \\
\hline 0 & 1649 & 0 & 0.00794 & 0.4764 & 1 & 5.23 & 0 \\
\hline 4 & 1567 & 1.216 & 0.009386 & 0.5631 & 0.507 & 6.1815 & 10.98 \\
\hline 8 & 1553 & 2.367 & 0.0132 & 0.792 & 0.357 & 8.695 & 24.34 \\
\hline 12 & 1537 & 3.219 & 0.0166 & 0.996 & 0.2992 & 10.935 & 29.72 \\
\hline 16 & 1525 & 4.512 & 0.0206 & 1.236 & 0.278 & 13.568 & 32.30 \\
\hline
\end{tabular}


Table 6: Performance of B60 Blend as fuel

\begin{tabular}{|l|l|l|l|l|l|l|l|}
\hline $\begin{array}{l}\text { Load } \\
(\mathbf{k g})\end{array}$ & $\begin{array}{l}\text { Speed } \\
(\mathbf{r p m})\end{array}$ & $\begin{array}{l}\text { BP } \\
(\mathbf{k W})\end{array}$ & $\begin{array}{l}\mathbf{M}_{\mathbf{f}} \\
(\mathbf{k g} / \mathbf{m i n})\end{array}$ & $\begin{array}{l}\mathbf{T F C} \\
(\mathbf{k g} / \mathbf{h r})\end{array}$ & $\begin{array}{l}\text { BSFC } \\
(\mathbf{k g} / \mathbf{k W}-\mathbf{h r})\end{array}$ & $\begin{array}{l}\text { H.I } \\
(\mathbf{k W})\end{array}$ & $\begin{array}{l}\boldsymbol{\eta}_{\text {th }} \\
(\boldsymbol{\%})\end{array}$ \\
\hline 0 & 1649 & 0 & 0.008802 & 0.52812 & 1 & 5.763 & 0 \\
\hline 4 & 1568 & 1.145 & 0.01082 & 0.6492 & 0.5854 & 7.0848 & 9.85 \\
\hline 8 & 1554 & 2.392 & 0.01366 & 0.8196 & 0.3693 & 8.944 & 23.78 \\
\hline 12 & 1538 & 3.328 & 0.018 & 1.08 & 0.3245 & 11.785 & 28.46 \\
\hline 16 & 1526 & 4.649 & 0.0225 & 1.35 & 0.3041 & 14.732 & 30.12 \\
\hline
\end{tabular}

Table 7: Performance of B100 as fuel

\begin{tabular}{|l|l|l|l|l|l|l|l|}
\hline $\begin{array}{l}\text { Load } \\
(\mathbf{k g})\end{array}$ & $\begin{array}{l}\text { Speed } \\
(\mathbf{r p m})\end{array}$ & $\begin{array}{l}\text { BP } \\
(\mathbf{k W})\end{array}$ & $\begin{array}{l}\mathbf{M}_{\mathbf{f}} \\
(\mathbf{k g} / \mathbf{m i n})\end{array}$ & $\begin{array}{l}\text { TFC } \\
(\mathbf{k g} / \mathbf{h r})\end{array}$ & $\begin{array}{l}\text { BSFC } \\
(\mathbf{k g} / \mathbf{k W}-\mathbf{h r})\end{array}$ & $\begin{array}{l}\text { H.I } \\
(\mathbf{k W})\end{array}$ & $\begin{array}{l}\mathbf{O}_{\mathbf{b} \text { th }} \\
(\boldsymbol{\%})\end{array}$ \\
\hline 0 & 1649 & 0 & 0.00876 & 0.5256 & 1 & 5.6626 & 0 \\
\hline 4 & 1568 & 1.121 & 0.01168 & 0.7 & 0.6319 & 7.5446 & 10.12 \\
\hline 8 & 1556 & 2.326 & 0.015 & 0.9 & 0.40558 & 9.7025 & 22.870 \\
\hline 12 & 1533 & 3.316 & 0.01877 & 1.126 & 0.3384 & 12.14 & 27.411 \\
\hline 16 & 1521 & 4.358 & 0.0239 & 1.434 & 0.323 & 15.353 & 28.906 \\
\hline
\end{tabular}

\section{RESULTS}

The results were obtained for various parameters and graphs for these parameters were plotted. The graphs was plotted against,

Load vs Speed

Load vs BFSC

Load vs Brake Thermal Efficiency

Load vs Brake Power

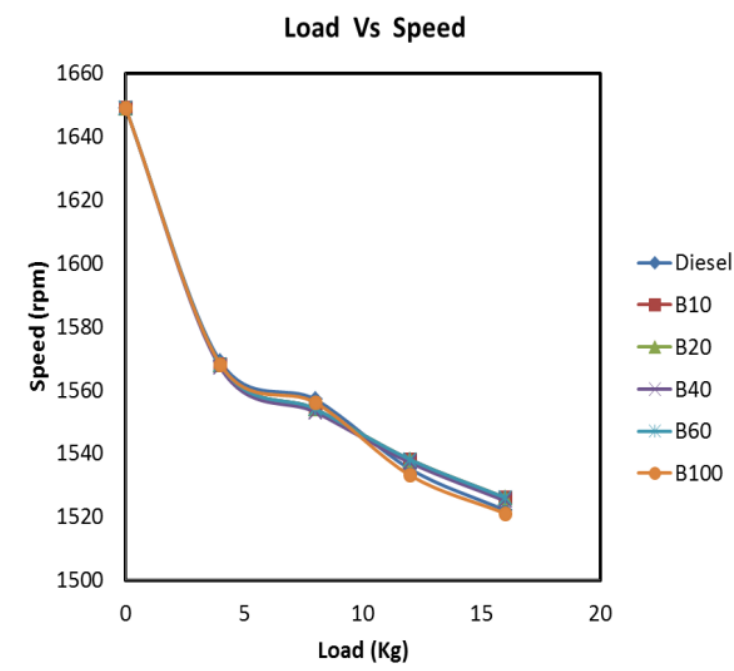

Fig 4: Load vs Speed

\section{Load Vs Brake Specific fuel consumption}

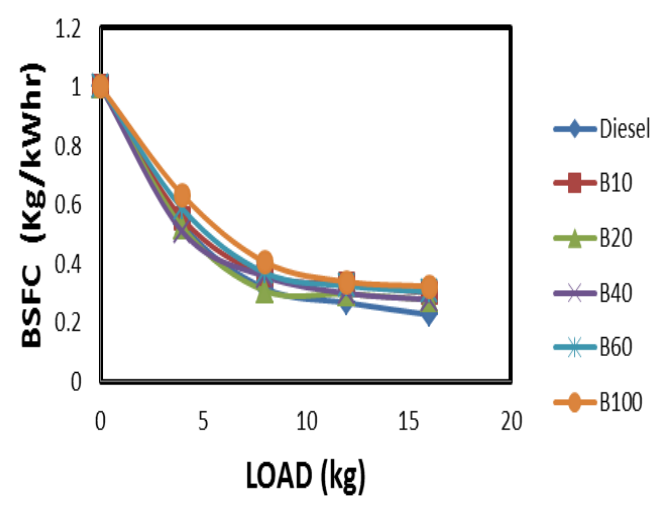

Fig 5: Load vs BSFC

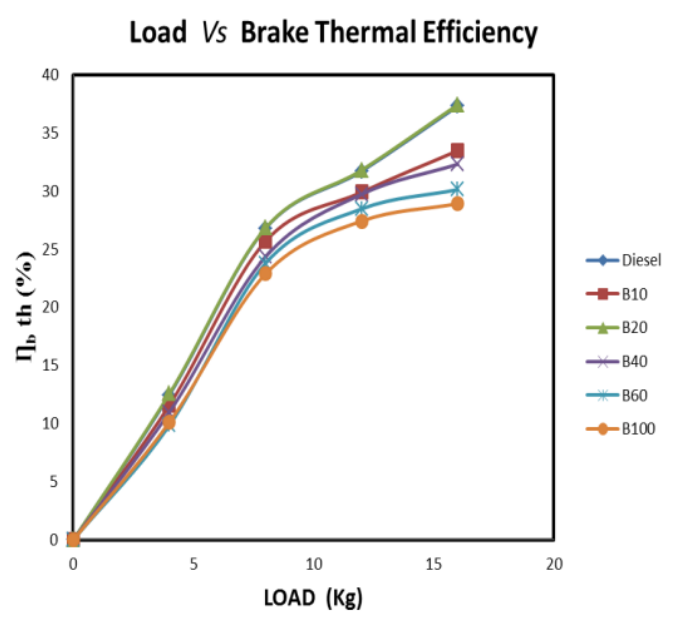

Fig 6: Load vs Brake Thermal Efficiency 


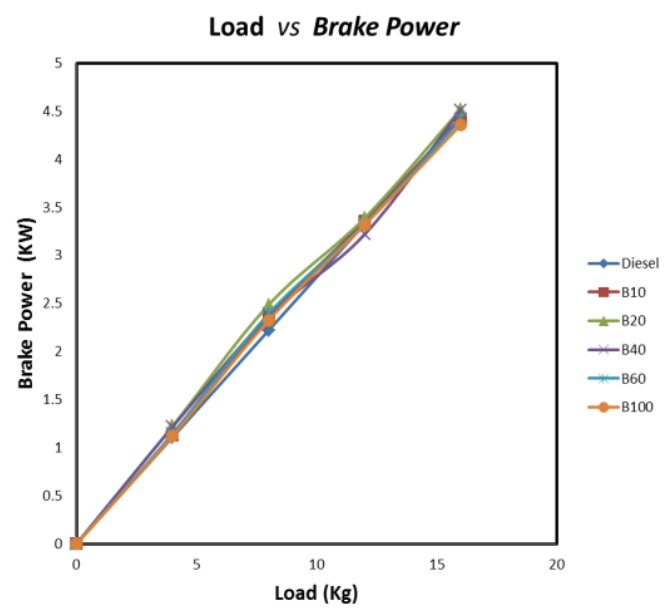

Fig 7: Load vs Brake Power

- As the load increases speed decreases for all the fuel.

- As the load increases the Brake Specific Fuel Consumption decreases observed for all the fuels.

- The brake specific fuel consumption of B20 blend is much less when compared to diesel.

- The brake thermal efficiency is much lower than the other blends observed for all the fuel

- The brake thermal efficiency of B20 fuel is highest than the other fuels

- The blends of bio-diesel have brake thermal efficiency higher than conventional diesel

- The Brake power of B20 is highest observed for all the fuel.

- Break power is increase by $12.5 \%$ at $4 \mathrm{~kg}$ load for B20 fuel when compared to diesel.

\section{CONCLUSIONS}

Tests indicate that the performance of the engine with methyl ester of cotton oil and its blend with diesel as a fuel is comparable with that of diesel. Hence methyl ester of cotton seed oil can be used as a diesel substitute. It is difficult to run the existing engine with the pure cotton seed oil because of its high flash and fire point. So, methyl ester of cotton seed oil or its blending with diesel is necessary.

By experimental results, we conclude that $20 \%$ to $40 \%$ blending of methyl ester of cotton seed oil with diesel has a greater advantage than the other blending ratios.

\section{SCOPE FOR FUTURE WORK}

A study of performance of the engine with the supply of methyl ester of cotton seed oil at higher temperature can be carried out. Higher temperatures results in lower viscosity of the fuel, hence an improvement in the performance of the engine can be expected. Various other combinations of the blends of methyl ester of cotton seed oil with diesel can be tried and the performance of the engine with these blends can be studied.

\section{REFERENCES}

[1]. David Chiaramonti, AnjaOasmaa, YrjoSolantausta, "Power generation using fast pyrolysis liquids from biomass", Renewable and Sustainable Energy Reviews, Vol.11 pp 1056-1086, 2007.

[2]. V. Bhardwaj, V. Singla, P. Gaikwad and G. Sharma, 'Study of Performance Characteristics of Compression Ignition Engine Fuelled with Blends of Biodiesel from Used Cottonseed Oil'.

[3]. Breda kegl and Stanislav pehan, influence of biodiesel on injection, Fuel spray, and engine characteristics, thermal science: Vol. 12 (2008), No. 2, pp. 171-182

[4]. Agarwal AK, Rajamanoharan K (2009). Experimental investigations of Yilmaz N, Morton B (2011). Effects of preheating vegetable oils on performance and emission characteristics of two diesel engines Biomass Bioenerg., 35: 2028-2033

[5]. B.K. Barnwal, M.P. Sharma, "Prospects of biodiesel production from vegetable oils India," Renewable and Sustainable Energy Reviews, Vol. 9, 2005, 363-378.

[6]. Jon H. Van Gerpen, Charles L. Peterson, Carroll E. Goering, Biodiesel: An Alternative Fuel for Compression Ignition Engines, For presentation at the 2007 Agricultural Equipment Technology Conference Louisville, Kentucky, USA 11-14 February 2007

[7]. Canakci and Vam Geroen (2003) - A pilot plant to produce biodiesel form high free fatty acid feedstockl, American society of agricultural engineers, 46(4), PP: 945954 